\title{
Brachystelma telanganense (Apocynaceae: Asclepiadoideae- Ceropegieae) - a new species from Telangana, India
}

\author{
Rasingam L. * \& J. Swamy \\ Botanical Survey of India, Deccan Regional Centre, Attapur, Hyderguda P.O., \\ Hyderabad, Telangana - 500 048, India. \\ *E-mail: rasingam@gmail.com
}

\begin{abstract}
A new species Brachystelma telanganense (Apocynaceae: Asclepiadoideae-Ceropegieae) is described from the Amrabad Tiger Reserve of Telangana state, India. This species is similar to B. gondwanense Govekar, Kahalkar \& Sardesai but differs in certain vegetative and floral characters.
\end{abstract}

Keywords: Amrabad Tiger Reserve, Eastern Ghats, Nagarjunasagar Srisailam Tiger Reserve.

\section{Introduction}

Recent phylogenetic/molecular studies on the tribe Ceropegieae Orb. ex Decne revealed that the genus Brachystelma R.Br. ex Sims and other genera of stapeliads are nested within Ceropegia L. making it paraphyletic (Meve \& LiedeSchumann, 2007; Surveswaran et al., 2009; Bruyns et al., 2015; Rodda \& Meve, 2017). Hence, Bruyns et al. (2017) proposed over 400 new combinations by merging Brachystelma and members of other stapeliad genera in the greatly enlarged genus Ceropegia making it monophyletic. Considering that most of the Indian species were missing from the studies of Bruyns et al. (2017), Surveswaran et al. (2020) preferred to retain the names Brachystelma and Ceropegia as separate entities based on their gross morphological feature of open flowers and tubular flowers, respectively.

Brachystelma, the second largest genus of the tribe Ceropegieae, has over 160 species distributed South

Received: 03.03.2020; Revised \& Accepted: 18.08.2020

Published Online: 30.09.2020 of the equator in Southeast Asia (including India) and North Australia (Masinde, 2007; Rasingam et al., 2013; Sardesai et al., 2016; Prasad et al., 2018). In India, the genus Brachystelma is known to have 33 species (Pullaiah et al., 2019), most of which occur in peninsular India growing sporadically along dry hill slopes of the Eastern Ghats and the adjoining Deccan region as well as the Western Ghats.

While working on the flora of the Amrabad Tiger Reserve, which was part of the Nagarjunasagar Srisailam Tiger Reserve (NSTR) in the erstwhile state of Andhra Pradesh and renamed Amrabad Tiger Reserve after the bifurcation of the state (Andhra Pradesh and Telangana), the authors collected a number of Brachystelma specimens from the open grasslands of dry deciduous forests in the area of Mallayalodhi in the year 2016. The tubers were collected from the wild and cultivated at the Botanical Survey of India, Deccan Regional Centre garden for further study. On observation, all the plants in the office garden flowered in the summer of 2018. Critical examination of the specimens with a M205A stereo microscope (Leica, Switzerland), perusal of relevant literature and comparison with herbarium specimens deposited at BSID and CAL revealed that they belong to a species that is closely related to $B$. gondwanense but differs in the number of flowers in the axils, the length of flowers and flowering shoots, and corona characters. Hence, this species is described here as new to science. 
Brachystelma telanganense Rasingam \& J. Swamy, sp. nov.

Fig. 1

Brachystelma telanganense is closely allied to $B$. gondwanense but differs in having 2-6 flowers in each axil, flowering shoots $12-35 \mathrm{~cm}$ long, interstaminal corona much taller than gynostegium, deeply 5-lobed, with each lobe deeply bifid at the apex, whereas B. gondwanense has 2-flowers in each axil, flowering shoots $8-12 \mathrm{~cm}$ long, interstaminal corona shallowly 5-lobed, slightly above the gynostegium and each lobe is shallowly bifid at the apex (Table 1).

Type: INDIA, Telangana, Botanical Survey of India, Deccan Regional Centre, Hyderabad (introduced from Mallayalodhi, Mahbubnagar district, Telangana state, India, N 16 18'19.411", E 7843'23.72", 780 m, 20.04.2018), L. Rasingam \& J. Swamy 8023, infl. (holo CAL!; iso BSID!).

Small tuberous, hysteranthous herbs, up to $17 \mathrm{~cm}$ tall; tubers globose to sub-globose, $3.5-4.5 \mathrm{~cm}$ across, brownish with few scattered roots. Stem solitary, terete, 1-2 mm in diam., striate, glabrous; internodes $2.5-4.5 \mathrm{~cm}$ long, gradually decreasing in length near apex. Leaves simple, sessile, opposite in 1-3 pairs, elliptic-lanceolate, 4-6 × 1.5-2 cm, acute to acuminate at apex, attenuate at base, margins entire, scabrous, greenish, glabrous above, glaucous beneath, chartaceous; midrib sunken above, prominently raised beneath; secondary nerves up to 5 pairs, obscure on both surfaces. Flowers on a long leafless, glabrous, pink shoot, 12-35 cm long, 2-3 mm wide, obtusely quadrangular at base, terete at apex, glabrous. Internodes up to $11 \mathrm{~cm}$ long, decreasing gradually towards the apex. Inflorescence axillary, 2-6 flowered at each axil; buds sharply angled, conical, c. $9 \times 3 \mathrm{~mm}$, twisted at the tip; pedicels stout, up to $8 \mathrm{~mm}$ long, scabrid to glabrous. Bracts linear, up to $8 \times 1 \mathrm{~mm}$, acuminate, slightly keeled at base with glandular hairs, apex smooth, margins scabrid. Bracteoles at the base of the pedicel, rarely below middle, linear, c. $2 \mathrm{~mm}$ long, acute at apex, recurved, minutely glandular hairy to scabrid. Calyx 5-lobed; lobes lanceolate, 2-4 mm long, c. $0.6 \mathrm{~mm}$ wide and united at base, acute at apex, brown, glabrous or rarely hairy. Corolla tube yellowish-white, without any coloured blotches. c. $2 \mathrm{~mm}$ long; lobes 5, dark brown at apex with yellowish-white patches at base, twisted at the tip, open gradually from base to tip and tips remain united, linear, 7-10 × 1-1.5 mm, involute at margins, acute at apex, sparsely white hairy only along the margins at base, glabrous above. Corona yellowish-white at base and dark brown at tips, biseriate, cupular-shaped, c. $2.3 \times 1.9 \mathrm{~mm}$. Interstaminal corona deeply 5-lobed, c. $1.0 \times 0.8 \mathrm{~mm}$,

Table 1. Comparison of diagnostic morphological characters of Brachystelma gondwanense and B. telanganense.

\begin{tabular}{|l|l|l|}
\hline Characters & $\begin{array}{l}\text { B. gondwanense Govekar, } \\
\text { Kahalkar \& Sardesai }\end{array}$ & B. telanganense Rasingam \& J. Swamy \\
\hline Leaves & $\begin{array}{l}3-7 \text { pairs, lanceolate, up to } 13 \mathrm{~cm} \text { long, } \\
\text { leathery }\end{array}$ & $\begin{array}{l}1-3 \text { pairs, elliptic-lanceolate, } \\
\text { up to } 6 \mathrm{~cm} \text { long, chartaceous }\end{array}$ \\
\hline Flowering shoot & $8-12 \mathrm{~cm}$ long & $12-35 \mathrm{~cm}$ long \\
\hline Flowers in each axil & 2 & $2-6$ \\
\hline Calyx & Glandular-hairy & Glabrous or rarely hairy \\
\hline Corolla & $\begin{array}{l}14-18 \times 1.5-2 \mathrm{~mm} \text {, hairy along the } \\
\text { margins and within }\end{array}$ & $\begin{array}{l}7-10 \times 1-1.5 \mathrm{~mm} \text {, hairy along the margins } \\
\text { at base, glabrous within }\end{array}$ \\
\hline Interstaminal corona & $\begin{array}{l}\text { Shallowly 5-lobed, slightly above the } \\
\text { gynostegium and each lobes shallowly } \\
\text { bifid at apex, densely short hairy within. }\end{array}$ & $\begin{array}{l}\text { Deeply 5-lobed, much taller than } \\
\text { gynostegium, each lobes deeply bifid } \\
\text { at apex, sparsely long hairy only at the tip } \\
\text { or glabrous. }\end{array}$ \\
\hline
\end{tabular}



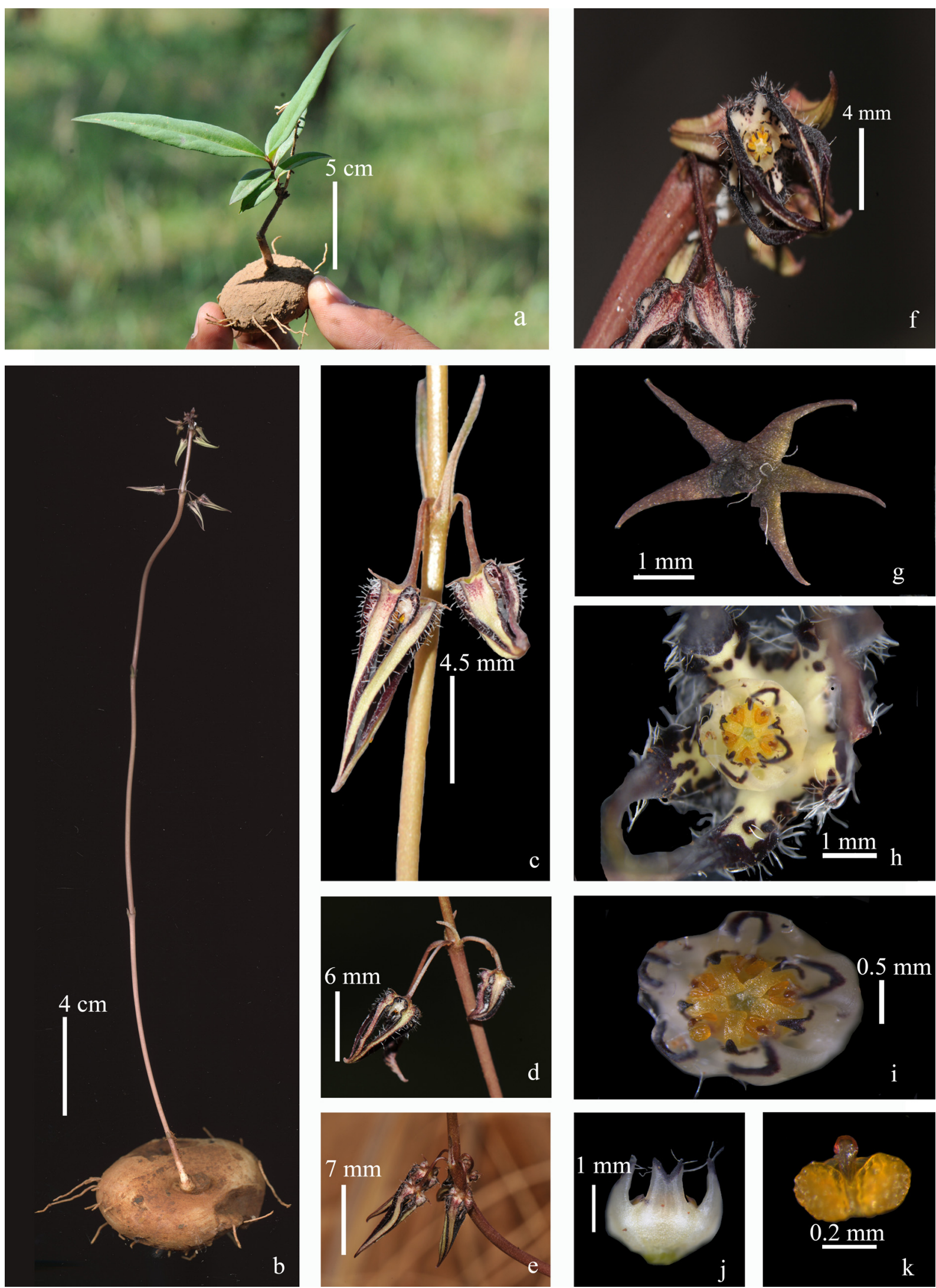

Fig. 1. Brachystelma telanganense Rasingam \& J. Swamy, sp. nov.: a \& b. Habit; c-e. Inflorescence; f. Flower; g. Calyx-adaxial view; h. Corolla-inner view; i. Corona-top view; j. Corona-lateral view; k. Pollinia (from L. Rasingam \& J. Swamy 8023). 
each lobes deeply bifid at apex, c. $0.4 \times 0.3 \mathrm{~mm}$, much taller than gynostegium, sparsely hairy to glabrous. Staminal corona incumbent on anther sacs, lanceolate, $0.5 \times 0.1-0.3 \mathrm{~mm}$, dark brown, acute at apex. Pollinarium c. $0.3 \times 0.4 \mu \mathrm{m}$; pollinium ovoid, c. $0.2 \times 0.2 \mathrm{~mm}$, attached to $c .0 .2 \mathrm{~mm}$ long pinkish red corpusculum by $c .0 .07 \mathrm{~mm}$ long yellow caudicles. Carpels 2, $0.8 \times 0.3 \mathrm{~mm}$ long. Follicles not seen.

Flowering \& fruiting: Flowering from March to May; fruiting not seen.

Habitat: It grows in open grasslands in dry deciduous forests at an elevation of $780 \mathrm{~m}$ in association with Euphorbia cristata B.Heyne ex Roth (Euphorbiaceae), Habenaria marginata Colebr. (Orchidaceae), Pentanema indicum (L.) Ling (Asteraceae) and Evolvulus alsinoides (L.) L. (Convolvulaceae).

Etymology: The species is named after the $29^{\text {th }}$ state of India, Telangana, from where it is collected and described.

Distribution: Brachystelma telanganense is presently known only from the Mallayalodhi area of Mahbubnagar district, Telangana.

Specimen examined: INDIA, Telangana, Amrabad Tiger Reserve, Mallayalodhi, Mahbubnagar district, 21.10.2016 (leaves), L. Rasingam \& J. Swamy 7387 (BSID).

\section{Acknowledgements}

Authors are grateful to Dr. A.A. Mao, Director, Botanical Survey of India, Kolkata and Dr. P.V. Prasanna, Scientist In-charge, Botanical Survey of India, Deccan Regional Centre, Hyderabad for facilities and encouragements and to the Principal Chief Conservator of Forest, Telangana Forest Department, for forest permission.

\section{Literature Cited}

BRUYNS P.V., KLAK C. \& P. HANÁCEK 2015. Recent radiation of Brachystelma and Ceropegia (Apocynaceae) across the Old World against a background of climatic change. Molecular Phylogenetics and Evolution 90: 4966. https://doi.org/10.1016/j.ympev.2015.04.015

BRUYNS P.V., KLAK C. \& P. HANÁĖEK 2017. A revised, phylogenetically-based concept of Ceropegia (Apocynaceae). South African Journal of Botany 112:399436. https://doi.org/10.1016/j.sajb.2017.06.021

MASINDE P.S. 2007. A revision of Brachystelma Sims (Apocynaceae: Asclepiadoideae - Ceropegieae) in East Africa. Kew Bulletin 62: 37-84.

MEVE U. \& S. LIEDE-SCHUMANN 2007. Ceropegia (Apocynaceae, Ceropegieae, Stapeliinae): paraphyletic, but still taxonomically sound. Annals of Missouri Botanical Garden 94: 392-406. https://doi.org/10.3417/00266493(2007)94[392:CACSPB]2.0.CO;2

PRASAD K., NARAYANA SWAMY A. \& U. MEVE 2018. Brachystelma ananthapuramense (Apocynaceae: Asclepiadoideae), a new species from Andhra Pradesh, India, Kew Bulletin 73: 16. https://doi.org/10.1007/ S12225-018-9740-Y

PULLAIAH T., KARUPPUSWAMY S. \& K.S. RAMA MURTHY 2019. Monograph on Brachystelma and Ceropegia in India. CRC Press, Boca Raton.

RASINGAM L., CHORGHE A.R., MEVE U., RAO M.S. \& P.V. PRASANNA 2013. Brachystelma penchalakonense (Apocynaceae: Asclepiadoideae) - a new species from Andhra Pradesh, India. Kew Bulletin 68: 663-667. https:/ /doi.org/10.1007/S12225-013-9477-6

RODDA M. \& U. MEVE 2017. Ceropegia laotica (Apocynaceae, Asclepiadoideae): the first new species of Ceropegia described from Laos. Gardens' Bulletin Singapore 69(2): 285-293. https://doi.org/10.26492/ gbs69(2).2017-07

SARDESAI M.M., KAMBALE S.S., GOVEKAR R.S. \& V.I. KAHALKAR 2016. Two new species of Brachystelma (Apocynaceae: Ceropegieae) from peninsular India. Rheedea 26(2): 60-67.

SURVESWARAN S., KAMBLE M.Y., YADAV S.R. \& M. SUN 2009. Molecular phylogeny of Ceropegia (Asclepiadoideae, Apocynaceae) from Indian Western Ghats. Plant Systematics and Evolution 281: 51-63. https:/ /doi.org/10.1007/s00606-009-0182-8

SURVESWARAN S., KAMBALE S.S., SRIVATSAV M., PUNEKAR S.A., YADAV S.R. \& K. PRAVEEN KARANTH 2020. Origin and diversification of Indian Ceropegieae (Apocynaceae) and possible relation to the Indian monsoon. Journal of Systematics and Evolution. https://doi.org/10.1111/jse.12578 